\title{
Protein C Prevents the Coagulopathic and Lethal Effects of Escherichia coli Infusion in the Baboon
}

\author{
F. B. Taylor, Jr., A. Chang, C. T. Esmon, A. D'Angelo," S. Vigano-D'Angelo," and K. E. Blick \\ Thrombosis/Hematology Research Program, Oklahoma Medical Research Foundation, Oklahoma City, Oklahoma 73104
}

\begin{abstract}
Gram-negative septicemia elicits multiple abnormalities of the coagulation system. Although products of coagulation can lead to clot formation, thereby potentiating organ damage, recent work has shown that low concentrations of thrombin can protect animals from the shock state. Because these amounts of thrombin also lead to formation in vivo of the anticoagulant enzyme, activated protein $\mathrm{C}$, we examined the role of protein $\mathrm{C}$ in modulation of Escherichia coli shock in baboons. First, we infused activated protein $\mathbf{C}$ and lethal concentrations of $\boldsymbol{E}$. coli organisms, which prevented the coagulopathic, hepatotoxic, and lethal effects of $E$. coli. Second, using an antibody to protein $\mathbf{C}$ we blocked protein $C$ activation in vivo to determine if this influenced the response to lethal and sublethal concentrations of $E$. coli organisms. Under these conditions the response to lethal concentrations of $E$. coli organisms was made more severe and the response to sublethal concentrations of $E$. coli was made lethal. The coagulopathic, hepatotoxic, and lethal responses in this latter case were prevented by infusion of exogenous protein $C$.
\end{abstract}

\section{Introduction}

Sepsis due to gram-negative bacteria often involves a shock state that can ultimately lead to death (1). Disturbances of the hemostatic system are closely linked to the development of this shock state. This led to the hypothesis that thrombin may mediate damage to the vascular system (2). Recent studies, however, have shown that low concentrations of thrombin prevent death due to endotoxin shock in the $\operatorname{dog}(3)$. This raised the possibility that products of the hemostatic system can serve to protect the vascular system from damage. One potential mechanism by which thrombin could lead to protection is through the activation of protein $\mathrm{C}$. The properties of protein $\mathrm{C}$ that make it a plausible candidate as the mediator of these protective effects are summarized below. Protein $\mathrm{C}$ activation occurs when low levels of thrombin are infused into dogs (4) or rabbits (5) and the levels required are similar to those that protect from septic shock (3). Activated protein $\mathrm{C}$ is a potent anticoagulant which is also capable of enhancing fibrinolysis $(6,7)$. The anticoagulant activity is manifested through the selective inactivation of Factors $V$, $\mathrm{Va}(8,9)$, and VIII, VIIIa $(10,11)$. In vitro, the inactivation of

Address reprint requests to Dr. Taylor. Drs. D'Angelo were on leave of absence from the Hemophilia and Thrombosis Center, A. Bianchi Bonomi, Policlinico Hospital, Milan, Italy.

Received for publication 12 May 1986 and in revised form 20 October 1986.

J. Clin. Invest.

(C) The American Society for Clinical Investigation, Inc.

0021-9738/87/03/0918/08 \$1.00

Volume 79, March 1987, 918-925 either Factor Va or Factor VIIIa is much more rapid than that of their precursors. Thus, in principle activated protein $\mathrm{C}$ can inhibit coagulation without significantly lowering the levels of coagulation factors. Finally, clinical studies have shown that protein $\mathrm{S}$ levels are significantly reduced in gram-negative sepsis. This could reflect either activation of protein $\mathrm{C}$ or, as proposed more recently, liver failure (12).

In this study we demonstrate that exogenously added activated protein $C$ prevents the coagulopathic response and lethal effects of $\mathrm{LD}_{100}$ concentrations of $E$. coli organisms in the baboon. In additional experiments we found that blocking protein $C$ activation in vivo leads to a more severe pathologic response to sublethal concentrations of $E$. coli organisms and that this response is prevented by coinfusion of activated protein $C$.

\section{Methods}

Experimentation requirements and procedures. Papio c. cynocephalus or Papio $c$ anubis baboons were purchased from a breeding colony maintained at the University of Oklahoma Health Sciences Center animal facility at the Oklahoma City zoo. These animals weighed 5-7 kg, had leukocyte concentrations of 5,000 to $7,000 / \mu l$, had hematocrits exceding $36 \%$, and were tuberculosis free. They were transferred to the Veteran's Administration Hospital animal facility and observed for a minimum of $10 \mathrm{~d}$ to assure adequate equilibration prior to experimentation. During recovery from shock, the baboons were observed daily and medically treated as appropriate. Surviving animals were euthanized after a minimum of $7 \mathrm{~d}$ with sodium pentobarbital.

Infusion procedures. The baboons were fasted overnight before study and immobilized the morning of the experiment with ketamine (14 mg/ $\mathrm{kg}$, i.m.). Sodium pentobarbital then was administered in the cephalic vein through a percutaneous catheter to maintain a light level of surgical anesthesia ( $2 \mathrm{mg} / \mathrm{kg}$ approximately every $45 \mathrm{~min})$. They were orally intubated and positioned on their left side on a heating pad. A femoral vein was exposed aseptically and cannulated in one hind limb for sampling blood. The percutaneous catheter was used to infuse the $E$. coli organisms and other agents. Gentamicin was given $(9 \mathrm{mg} / \mathrm{kg}$ i.v. $)$ at $\mathrm{T}+120 \mathrm{~min}$ for $75 \mathrm{~min}$ and then $(4.5 \mathrm{mg} / \mathrm{kg})$ at $\mathrm{T}+360$ and $\mathrm{T}+540 \mathrm{~min}$ for $30 \mathrm{~min}$. Gentamicin $(4.5 \mathrm{mg} / \mathrm{kg}$ i.m. $)$ then was given at the end of the experiment and twice daily for $3 \mathrm{~d}$.

Sampling procedures and assays. Mean systemic arterial pressure and heart rate were monitored with a Dinamap TM Research Monitor model 1255 (Critikon Inc., Tampa, FL) pressure gauge. Temperature was measured with a Telethermometer (Yellow Springs Instrument Co., Yellow Springs, $\mathrm{OH}$ ). These measurements were made and blood samples were collected at $T-30,0,+60,+120,+180,+240,+360,+480,+600$ $\mathrm{min}$, and $24 \mathrm{~h}$. In some experiments the observation period was extended to $\mathrm{T}+720 \mathrm{~min}$. T-0 designates the point at which the infusion of $E$. coli was started. Not more than $10 \%$ of the baboon's estimated total blood volume $(70 \mathrm{ml} / \mathrm{kg})$ was withdrawn over the $10-12-\mathrm{h}$ monitoring period. The blood sampled at each drawing included: $1 \mathrm{ml}$ anticoagulated with ethylenediaminotetraacetic acid for complete blood count (CBC), ${ }^{1}$ he-

1. Abbreviations used in this paper: $\mathrm{CBC}$, complete blood count; MES, morpholinoethane-sulfonic acid; SGPT, serum glutamic pyruvic transaminase. 
matocrit, platelet and differential counts; $2.0 \mathrm{ml}$ anticoagulated with $3.8 \%$ sodium citrate for fibrinogen (13), whole blood clot lysis (14), rocket immunoelectrophoretic assays of baboon protein C, and HPC-4 (rabbit anti-mouse IgG monoclonal antibody to human protein $\mathrm{C}$, see description below); $1.0 \mathrm{ml}$ in trasylol/thrombin for fibrin degradation products (15); $1.0 \mathrm{ml}$ of clotted blood for serum glutamic pyruvic transaminase (SGPT) (16); and $1.0 \mathrm{ml}$ at $\mathrm{T}-0, \mathrm{~T}+120$, and $\mathrm{T}+360 \mathrm{~min}$ for colony counts (17). Additional 1-ml samples of blood anticoagulated with sodium citrate were drawn at times between $\mathrm{T}+120$ and $360 \mathrm{~min}$ for assays of fibrinogen levels during infusion of activated protein $\mathrm{C}$.

Coagulation Factor V (18) and VIII (19) levels were determined by standard clotting assays. For samples assayed in the presence of activated protein $C$, it was necessary to inhibit activated protein $C$ to prevent interference in the assay. This was accomplished by adding goat antihuman protein C IgG to the samples at a final concentration of $2 \mathrm{mg} /$ $\mathrm{ml}$. The antibody was incubated with the plasma for $10 \mathrm{~min}$ before the assay. At this concentration the antibody totally blocks the anticoagulant activity of activated protein $\mathrm{C}(5 \mu \mathrm{g} / \mathrm{ml})$ in the standard Factor Xa onestage assay (9).

Protein $C$ antigen levels. Protein $\mathrm{C}$ antigen levels in baboon plasma were measured by conventional Laurell rocket electrophoresis (20). Goat polyclonal IgG against human protein $C$ was incorporated at $0.03 \mathrm{mg}$ / $\mathrm{ml}$ final concentration into $1 \%$ agarose plates (SEAKEM ME, Agarose, FMC Corp., Marine Colloids Div., Rockland, MS) made up with Paragon B-2 buffer (Beckman Instruments, Inc., Fullerton, CA) containing 2 mM EDTA. The same buffer was employed for electrophoresis. Plasma samples of $15 \mu \mathrm{l}$ were electrophoresed overnight at $2 \mathrm{~mA} / \mathrm{cm}$ at $25^{\circ} \mathrm{C}$. Calibration curves were prepared with serial dilutions of baboon plasma in the electrophoresis buffer $(100,50,25,12.5,6.25 \%)$. The assay was sensitive to $10 \%$ baboon plasma levels. Human and baboon plasma were compared on a calibration curve obtained by addition of purified protein $\mathrm{C}$ to human protein $\mathrm{C}$-depleted plasma. Plasma protein $\mathrm{C}$ concentrations of $3.8 \mu \mathrm{g} /$ liter and $5 \mu \mathrm{g} / \mathrm{ml}$ were calculated for human and baboon plasma, respectively.

HPC-4 levels in baboon plasma were measured by rocket immunoelectrophoresis (20). A rabbit antiserum directed against mouse immunoglobulins (Gateway Immunosera Co., Chatokia, IL) was incorporated into $1 \%$ agarose plates at $0.3 \%$ (vol/vol) final concentration. Samples of $7 \mu \mathrm{l}$ were electrophoresed as described for protein $\mathrm{C}$ antigen measurement. Baboon plasma containing $50 \mu \mathrm{g} / \mathrm{ml} \mathrm{HPC}-4$ was diluted into electrophoresis buffer to construct a calibration curve. The assay was sensitive to HPC-4 plasma levels of $3 \mu \mathrm{g} / \mathrm{ml}$.

Preparation of HPC-4. HPC-4, the $\mathrm{Ca}^{2+}$-dependent murine monoclonal antibody utilized to purify protein $\mathrm{C}$ and block protein $\mathrm{C}$ activation, was purified by $\mathrm{NH}_{4} \mathrm{SO}_{4}$ fractionation of mouse ascites fluid, and chromatography on QAE-Sephadex Q50 (Sigma Chemical Co., St. Louis, MO). The sample was applied in $0.027 \mathrm{M}$ Tris- $\mathrm{PO}_{4}, \mathrm{pH} 6.3$ at room temperature and eluted with a linear gradient from 0 to $0.4 \mathrm{M} \mathrm{NaCl}$. HPC-4, an IgG 1, corresponded to the last major protein peak to elute from the column. For $200 \mathrm{ml}$ of ascites fluid a $2.5 \times 40 \mathrm{~cm}$ column was employed and eluted at room temperature with a $1 \mathrm{~L}$ (total volume) gradient. HPC-4 to be infused into the baboons was further purified by gel filtration on a $1.5 \times 100 \mathrm{~cm}$ Biogel A-15 agarose (Bio-Rad, Richmond, CA) column equilibrated in pyrogen free physiological saline. Fractions of $\mathrm{HPC}-4$ were mixed with equal volumes of saturated $\mathrm{NH}_{4} \mathrm{SO}_{4}$ and the precipitate was harvested by centrifugation and the pellet redissolved in $1.5 \mathrm{ml}$ physiological saline before chromatography.

Properties of HPC-4. The properties of the HPC-4 monoclonal antibody are as follows: it binds human protein $\mathrm{C}$ only in the presence of $\mathrm{Ca}^{2+}$; it binds to the reduced carboxymethylated protein $\mathrm{C}$ heavy chain; it blocks protein $\mathrm{C}$ activation but does not bind or inactivate activated protein $\mathrm{C}$ or activated protein $\mathrm{C}$ bound to its plasma inhibitor.

That HPC-4 also binds baboon protein $\mathrm{C}$ in the presence of $\mathrm{Ca}^{2+}$ and blocks baboon protein $\mathrm{C}$ activation was demonstrated in the following set of experiments. $2 \mathrm{ml}$ of either human or baboon plasma were incubated with $0.2 \mathrm{ml}$ of packed HPC-4 Affigel 10 beads after plasma recalcification and heparinization as previously described (21). The amount of baboon and human protein $\mathrm{C}$ recovered in the EDTA eluate was found to represent $85 \%$ to $90 \%$ of the starting plasma protein C levels as assessed by rocket immunoelectrophoresis using a polyclonal antihuman protein $\mathrm{C}$ goat IgG antibody. After recalcification of the EDTA eluates, 0.4-ml aliquots were activated with $50 \mu$ l of packed thrombinthrombomodulin Affigel 10 beads (21), to give a $90-\mu \mathrm{M}$ final thrombinthrombomodulin concentration, for $90 \mathrm{~min}$ at $37^{\circ} \mathrm{C}$ in the presence of increasing concentrations of HPC-4 (up to $300 \mu \mathrm{g} / \mathrm{ml}$ ). After removal of the thrombin-thrombomodulin beads, the activated samples were tested for both anticoagulant and amidolytic protein C activity (21). Even after the prolonged 90-min incubation, activation of both human and baboon protein $C$ was inhibited to a similar extent by HPC-4 with $50 \%$ inhibition at $60-70 \mu \mathrm{g} / \mathrm{ml} \mathrm{HPC}-4$ (Fig. 1 a).

The HPC-4 dependent inhibition of the initial rate of protein $\mathrm{C} \mathrm{ac}-$ tivation by thrombin-thrombomodulin complex was evaluated at 0,40 , and $240 \mu \mathrm{g} / \mathrm{ml} \mathrm{HPC-4-concentration.} \mathrm{Protein} \mathrm{C} \mathrm{isolated} \mathrm{from} \mathrm{human}$ and baboon plasma (4-5 $\mu \mathrm{g} / \mathrm{ml})$ as described was incubated with HPC4 for $60 \mathrm{~min}$ at $37^{\circ} \mathrm{C}$ in the presence of $2 \mathrm{mM} \mathrm{CaCl}_{2}$. Protein $\mathrm{C}$ activation then was initiated by addition of $50 \mu \mathrm{l}$ of packed thrombin-thrombomodulin Affigel 10 beads ( $40 \mathrm{nM}$ thrombin-thrombomodulin complex). Aliquots $(0.1 \mathrm{ml})$ were removed at fixed times and assayed for activated protein $\mathrm{C}$ amidolytic activity. Similar results were obtained for baboon and human protein $\mathrm{C}$. The initial rate of protein $\mathrm{C}$ activation was reduced $90-95 \%$ in the presence of $40 \mu \mathrm{g} / \mathrm{ml} \mathrm{HPC}-4$ (Fig. $1 b$ ).

Preparation of protein $C$ from KONYNE. Protein $\mathrm{C}$ and activated protein $C$ were prepared from KONYNE (a gift from Cutter Laboratories, Berkeley, CA), as follows: Each of 15 bottles $(8,000 \mathrm{U})$ were reconstituted to twice the suggested concentration with $10 \mathrm{ml}$ of $0.02 \mathrm{M}$ Tris $\mathrm{HCl}, 10$ $\mathrm{mM}$ benzamidine $\mathrm{HCl}, \mathrm{pH}$ 7.5. The reconstituted protein was desalted by chromatography on a column $(5 \times 35 \mathrm{~cm})$ of Sephadex G-75 equilibrated in $0.1 \mathrm{M} \mathrm{NaCl}, 0.02$ Tris $\mathrm{HCl}, 10 \mathrm{mM}$ benzamidine, $\mathrm{pH}$ 7.5. The eluate was made $4 \mathrm{mM}$ in $\mathrm{CaCl}_{2}$ and applied to a column $(2.5$ $\times 27 \mathrm{~cm}$ ) filled with a calcium-dependent monoclonal antibody to protein C (HPC4) linked covalently to Affigel 10 to give a final concentration of $5 \mathrm{mg} / \mathrm{ml}$. The column was equilibrated at room temperature in 0.1 $\mathrm{M} \mathrm{NaCl}, 0.02 \mathrm{M}$ Tris- $\mathrm{HCl}, 10 \mathrm{mM}$ benzamidine $\mathrm{HCl}, 2 \mathrm{mM} \mathrm{CaCl}, \mathrm{pH}$ 7.5 and the sample applied at $150 \mathrm{ml} / \mathrm{h}$. The column was washed with $750 \mathrm{ml}$ of $0.5 \mathrm{M} \mathrm{NaCl}$ with all other buffer components as in the equilibration buffer. The column was washed with $150 \mathrm{ml}$ of $0.1 \mathrm{M} \mathrm{NaCl}$, $0.02 \mathrm{M}$ Tris $\mathrm{HCl}, 2 \mathrm{mM} \mathrm{CaCl}, \mathrm{pH} 7.5$ and then eluted with $0.1 \mathrm{M}$ $\mathrm{NaCl}, 0.02 \mathrm{M}$ Tris $\mathrm{HCl}, 2 \mathrm{mM}$ EDTA, pH 7.5.

Preparation and assay of activated protein $C$. Approximately $30 \mathrm{mg}$ of protein $\mathrm{C}$ was recovered in $25 \mathrm{ml}$ and then activated with bovine thrombin $(5 \% \mathrm{wt} / \mathrm{wt})$ for $3 \mathrm{~h}$ at $37^{\circ} \mathrm{C}$. Activated protein $\mathrm{C}$ then was isolated by chromatography on a DEAE-Sepharose column $(1.5 \times 25$ cm) equilibrated in $0.1 \mathrm{M} \mathrm{NaCl}, 5 \mathrm{mM}$ morpholino-ethane-sulfonic acid (MES)-HCl, pH 6.0. The column was developed with a linear gradient from 0.1 to $0.6 \mathrm{M} \mathrm{NaCl}$ in $5 \mathrm{mM}$ MES-HCl, pH $6.0(220 \mathrm{ml}$ total
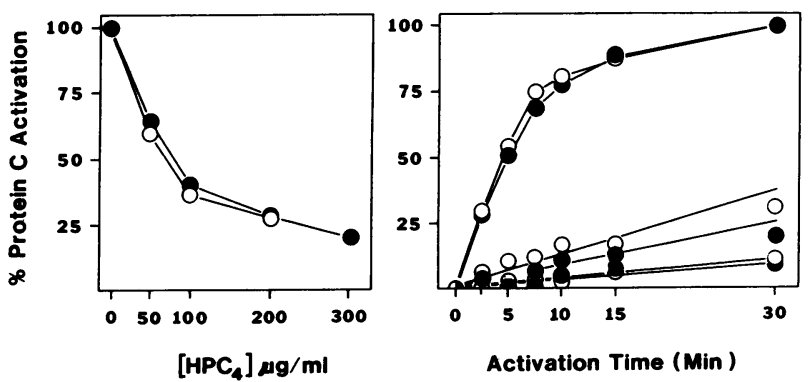

Figure 1. In vitro assay of HPC-4 inhibition of protein $\mathrm{C}$ activation by thrombin-thrombodulin Affigel beads. Inhibition of protein $\mathrm{C}$ activation as a function of HPC-4 concentration (a), human plasma (open circles), baboon plasma (solid circles). Inhibition of protein $\mathrm{C}$ activation by 0,40 , and $240 \mu \mathrm{g} / \mathrm{ml} \mathrm{HPC-} 4$ as a function of activation time (b), human plasma (open circles), baboon plasma (solid circles). 
volume). $2-3 \mathrm{ml}$ fractions were collected and stored at $4^{\circ} \mathrm{C}$ for no more than $5 \mathrm{~d}$ before use.

Activated protein $\mathrm{C}$ amidolytic activity was assayed with spectrozyme $\mathrm{Ca}$ (American Diagnostica, Greenwich, CT). The assay was performed at $22^{\circ} \mathrm{C}$ at a final substrate concentration of $0.1 \mathrm{mM}$ in $0.1 \mathrm{M} \mathrm{NaCl}$, $0.02 \mathrm{M}$ Tris $\mathrm{HCl}, 1 \% \mathrm{wt} / \mathrm{wt}$ gelatin, $\mathrm{pH}$ 7.5. The purified activated protein $\mathrm{C}$ at $10 \mathrm{nM}$ final concentrations gave an A405/min of between 0.0375 and 0.055 . Protein purified from frozen plasma with the HPC-4 monoclonal antibody and subsequently activated gave A405/min of 0.06 for the same concentration of activated protein C. KONYNE-derived activated protein $\mathrm{C}$ had 50 to $60 \%$ the anticoagulant activity (21) of an identical concentration of activated protein $\mathrm{C}$ purified from fresh frozen plasma.

As a further characterization of this activated protein $\mathrm{C}$, the in vitro half life of the KONYNE derived activated protein $\mathrm{C}$ was evaluated in baboon and in human plasma. Plasma aliquots $(0.7 \mathrm{ml})$ were incubated at $37^{\circ} \mathrm{C}$ with either 2.3 or $10.7 \mu \mathrm{g} / \mathrm{ml}$ activated protein C. Aliquots $(80$ $\mu \mathrm{l})$ were removed after $12,30,45,60,100$, and $120 \mathrm{~min}$ and the residual amidolytic activity of activated protein $\mathrm{C}$ was measured. Similar half lives were calculated for both activated protein $\mathrm{C}$ concentrations in baboon and human plasma $\left(2.3 \mu \mathrm{g} / \mathrm{ml}\right.$ activated protein $\mathrm{C}$ : $\mathrm{T}_{\mathrm{H} / 2}$ of $25 \mathrm{~min}$; $10.7 \mu \mathrm{g} / \mathrm{ml}$ activated protein $\mathrm{C}: \mathrm{T}_{\mathrm{y}_{2}}$ of $21 \mathrm{~min}$ ).

Preparation of $E$. coli organisms. E. coli (organisms) Type B were isolated from a stool specimen at Children's Memorial Hospital, Oklahoma City. They were stored in the lyophilized state at $4^{\circ} \mathrm{C}$ after growth in tryptic soybean agar and reconstituted and characterized as described by Hinshaw et al. (17).

\section{Results}

Infusion of $E$. coli alone into baboons at concentrations of 4 $\times 10^{10}$ organisms $/ \mathrm{kg}$ produced a shock state that was accompanied first by a decrease of the fibrinogen level to $20 \%$ of control at T+360 min, and then by an increase of the SGPT level above the normal range beginning at $T+360 \mathrm{~min}$. These responses were accompanied by a steady gradual decline of protein $\mathrm{C}$ levels to 50 to $40 \%$ of control at $\mathrm{T} \pm 600 \mathrm{~min}$ (Fig. 2). The five baboons

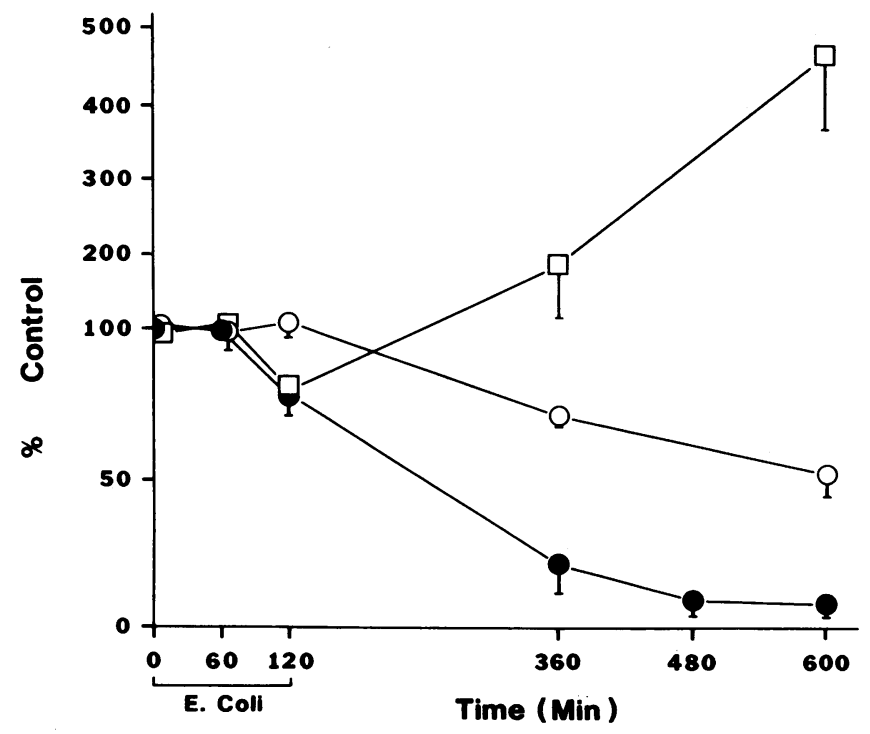

Figure 2. Response of baboons to an infusion of lethal $\left(\mathrm{LD}_{100}\right)$ concentrations of $E$. coli. After an equilibration period of $30 \mathrm{~min}, 4$ $\times 10^{10} \mathrm{E}$. coli organisms $/ \mathrm{kg}$ i.v. were infused from $\mathrm{T}-0$ to $\mathrm{T}+120 \mathrm{~min}$. The parameters shown are: fibrinogen (solid circles), protein C/activated protein C (open circles) and SGPT (open squares), $(n=5)$. The bars indicate the standard deviation observed in five animals. so treated also experienced a prompt fall in leukocyte count to $20 \%$ of control at $\mathrm{T}+60 \mathrm{~min}$, a clinically significant drop in mean systemic arterial pressure from 67 to 48 beginning at $\mathrm{T}+360 \mathrm{~min}$, a steady decline in platelet count to 20 to $30 \%$ of control at $\mathrm{T}+600 \mathrm{~min}$, and death at 24 to $32 \mathrm{~h}$. The dominant postmortem findings in this series and in all animals dying of septic shock included gross and microscopic evidence of liver enlargement with hepatocellular degeneration, bilateral adrenal hemorrhage, and interstitial pulmonary edema with polymorphonuclear (PMN) leukocyte infiltration. This protocol has been characterized previously in the baboon and mimics the clinical progression of septicemia and shock in humans (22).

Infusion of $E$. coli plus activated protein $C$ prevented fibrinogen levels from falling below $70 \%$ of control (Fig. 3). The SGPT levels remained within the normal range throughout the study while the protein $\mathrm{C} /$ exogenous activated protein $\mathrm{C}$ levels rose to a maximum of $816 \%$ of control at $T+240 \mathrm{~min}$. The four baboons so treated experienced a prompt fall in leukocyte count to $10-20 \%$ control at $\mathrm{T}+60 \mathrm{~min}$, no drop in mean systemic arterial pressure, and a decline in platelet counts to 60 to $50 \%$ of control at $\mathrm{T}+600 \mathrm{~min}$. All four animals were permanent ( 7 d) survivors. During this infusion plasma fibrinogen levels were determined every $15 \mathrm{~min}$ between 120 and $360 \mathrm{~min}$. If fibrinogen levels fell to $75-70 \%$ of control, the rate of infusion of activated protein $\mathrm{C}$ was doubled from $4 \mu \mathrm{g} / \mathrm{kg}$ per min to as high as 64 $\mu \mathrm{g} / \mathrm{kg}$ per min until the fibrinogen levels returned toward $100 \%$ of control. A total of 7 to $8 \mathrm{mg} / \mathrm{kg}$ body wt of activated protein $\mathrm{C}$ infused over an 8-10-h period was required.

In the above experiments high levels of activated protein $\mathrm{C}$ were employed for a prolonged period. While the minimum dose required is yet to be established in three animals that re-

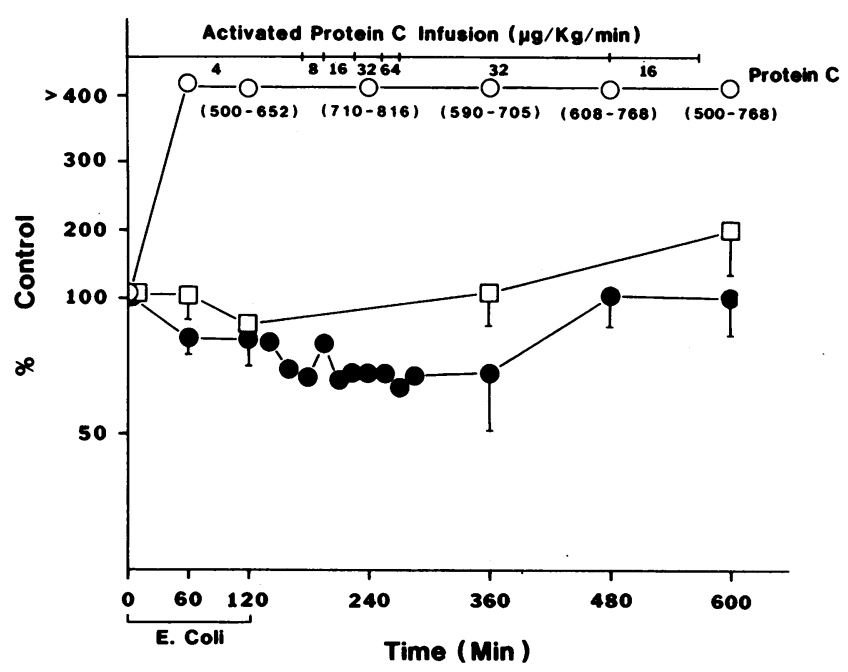

Figure 3. Response of a baboon to an infusion of $E$. coli plus activated protein C. After an equilibration period of $30 \mathrm{~min}$ a bolus of $0.5 \mathrm{mg}$ / $\mathrm{kg}$ i.v. of activated protein $\mathrm{C}$ was given at $\mathrm{T}-10 \mathrm{~min}$ followed by an infusion of $4 \times 10^{10} \mathrm{E}$. coli organisms $/ \mathrm{kg}$ i.v. from $\mathrm{T}-0$ to $\mathrm{T}+120 \mathrm{~min}$. Activated protein $\mathrm{C}(4 \mu \mathrm{g} / \mathrm{kg}$ per $\mathrm{min})$ was also started at $\mathrm{T}-0$. The rate of activated protein $C$ infusion was adjusted to maintain the fibrinogen level at no less than $70 \%$ normal. The rates of activated protein $C$ infusion are shown at the top of the figure. Measurement of fibrinogen levels were performed every $15 \mathrm{~min}$ from $T+120$ to $T+360 \mathrm{~min}$ in order to regulate the rate of activated protein $\mathrm{C}$ infusion. The parameters shown are: fibrinogen (solid circles), protein C/activated protein C (open circles), and SGPT (open squares), $(n=4)$. 
ceived 1,3 , and $4 \mathrm{mg} / \mathrm{kg}$ body wt of activated protein $\mathrm{C}$, respectively over a shorter 2-h period, the coagulopathic and hepatotoxic effects appeared over the ensuing 14 to $22 \mathrm{~h}$, followed by death at 24 to $32 \mathrm{~h}$. A single baboon receiving $10 \mathrm{mg} / \mathrm{kg}$ body wt of activated protein $\mathrm{C}$ over this 2 -h period survived for $7 \mathrm{~d}$ without a significant coagulopathic or hepatotoxic response. In none of the animals was there any evidence of bleeding complications observed at any time during the study.

From the data in Fig. 3, it is clear that activated protein $\mathrm{C}$ at these levels produced an effective anticoagulant response to $E$. coli. Although most investigators believe that the activated forms of Factor V and VIII are the principle targets for expression of activated protein $\mathrm{C}$ anticoagulant activity, it is possible to inactivate their precursors at least in vitro. If this were the case, the anticoagulant response would be due to severe depression of the levels of these coagulation factors. To test this possibility, Factor VIII and Factor V assays were performed on plasma samples from baboons receiving activated protein $\mathrm{C}$ alone and with $E$. coli (Table I). In both studies the Factor $\mathrm{V}$ and the Factor VIII levels stayed relatively close to their initial values provided, however, that the samples of blood were drawn into syringes containing antibody to protein $\mathrm{C}$. This was especially true of the Factor VIII assay (Table I). From these data it is clear that activated protein $\mathrm{C}$ can function as an in vivo anticoagulant without suppressing Factor V or VIII levels. Finally, it is of interest that activated protein $\mathrm{C}$ actually inhibits the Factor $\mathrm{V}$ consumption that occurs following $E$. coli infusion (Table II).

The observation that protein $C$ as well as fibrinogen fell suggested that endogenous protein $\mathrm{C}$ might be activated in the host response to $E$. coli infusion. This observation plus that showing that exogenous activated protein $\mathrm{C}$ attenuated the coagulopathic response and protected against the lethal effects of $E$. coli infusion suggested that the endogenous protein $C$ system might play a protective role. If endogenous protein $\mathrm{C}$ plays a protective role, then animals in which the activation of protein $C$ is blocked should experience a more severe coagulopathic response and be at greater risk to septic shock after infusion of $E$. coli. To test this hypothesis we created an artificial model in which activation

Table I. Factor $V$ and Factor VIII Levels in Baboons Receiving Activated Protein C Alone and Activated Protein C Plus E. coli ( $\left.L D_{100}\right)$

\begin{tabular}{lllll}
\hline Factor V & & & Factor VIII & \\
\cline { 1 - 3 } Time & Plasma & $\begin{array}{l}\text { Plasma plus } \\
\text { anti-protein } \\
\text { antibody }\end{array}$ & & $\begin{array}{l}\text { Plasma plus } \\
\text { anti-protein C } \\
\text { antibody }\end{array}$ \\
\hline
\end{tabular}

\section{$\min$}

Activated protein $\mathrm{C}$ infusion

$\begin{array}{llr}\mathrm{T}-0 & 100 & 100 \\ \mathrm{~T}+20^{\prime} & 75 & 97 \\ \mathrm{~T}+35^{\prime} & 62.5 & 102 \\ \mathrm{~T}+50^{\prime} & 60 & 8 \\ \mathrm{~T}+60^{\prime} & 62.5 & 97\end{array}$

100
97
102
85
97

$\begin{array}{lr}100 & 100 \\ \text { ND* } & 106 \\ \text { ND } & 123 \\ \text { ND } & 89 \\ \text { ND } & 102\end{array}$

Activated protein $\mathrm{C}$ plus $E$. coli $\left(\mathrm{LD}_{100}\right)$ infusion

$\begin{array}{lrrrr}T+0 & 100 & 120 & \text { ND } & 100 \\ T+60^{\circ} & 100 & 128 & \text { ND } & 448 \\ T+120^{\circ} & 71 & 120 & \text { ND } & 308 \\ T+360^{\circ} & 80 & 63 & \text { ND } & 111 \\ \text { Next day } & 25 & - & 60 & 68\end{array}$

* ND, not detectable.
Table II. Factor V Levels in Baboons Receiving E. coli (LD 100$)$ Alone and E. coli Plus Activated Protein C

\begin{tabular}{lll}
\hline Time & E. coli & $\begin{array}{l}\text { E. coli plus } \\
\text { activated protein C }\end{array}$ \\
\hline$T-0$ & 100 & 100 \\
$T+60^{\prime}$ & 80 & 101 \\
$T+120^{\prime}$ & 47 & 71 \\
$T+360^{\prime}$ & 10 & 80 \\
\hline
\end{tabular}

of endogenous protein $\mathrm{C}$ was blocked by infusion of HPC-4 antibody to protein $C$ prior to $E$. coli.

Under these conditions infusion of $E$. coli $\left(\mathrm{LD}_{100}\right)$ produced a coagulopathic response which was more severe than that following $E$. coli $\left(\mathrm{LD}_{100}\right)$ alone. The fibrinogen level decreased to less than $10 \%$ of its control at $T+120 \mathrm{~min}$. The SGPT level increased beginning at $\mathrm{T}+360 \mathrm{~min}$ while the protein $\mathrm{C}$ level did not decrease (Fig. 4). The three baboons so treated also experienced a prompt fall in leukocyte count to $20 \%$ of control at $T+60$ min, a clinically significant drop in mean systemic arterial pressure from 97 to 51 beginning at $\mathrm{T}+120 \mathrm{~min}$, a steady decline in platelet count to $20 \%$ of control at $\mathrm{T}+600 \mathrm{~min}$, and death at 16-24 h.

Infusion of antibody to protein $\mathrm{C}$ alone produced none of these responses. The protein $C$ levels remained within $90 \%$ of baseline throughout the $10-\mathrm{h}$ period of the study. In the three baboons so treated the systemic arterial pressure and general clinical status remained stable throughout the study and they survived for the full 7-d postoperative period. There was however, a rise in leukocyte count above control between $T+120$ and $T+360 \mathrm{~min}$. The plasma levels of HPC -4 as measured by rocket immunoelectrophoresis against rabbit anti-mouse IgG ranged from 25 to $200 \mu \mathrm{g} / \mathrm{ml}$ at $\mathrm{T}-0$. They remained at these levels in all experiments including those in which $E$. coli and activated protein $C$ were infused out to $T+600 \mathrm{~min}$. At $24 \mathrm{~h}$ these levels had declined to $60 \% \pm 15 \%$ of their control $(\mathrm{T}-0)$ values.

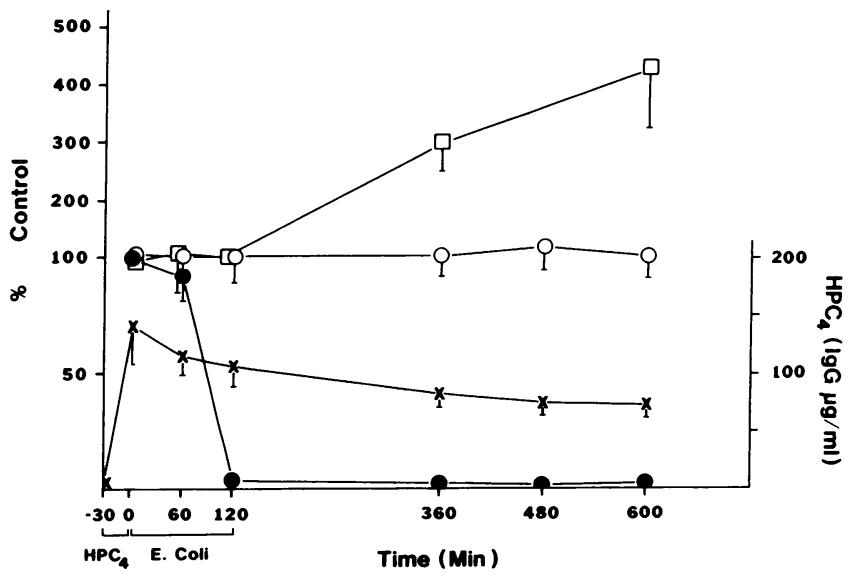

Figure 4. Response of baboons to an infusion of HPC-4 followed by lethal concentrations of $E$. coli. After an equilibration period of 30 $\mathrm{min}, 4 \mathrm{mg} / \mathrm{kg}$ i.v. of HPC-4 were infused for $30 \mathrm{~min}$. After a second equilibration period of $30 \mathrm{~min}, 4 \times 10^{10} \mathrm{E}$. coli organisms $/ \mathrm{kg}$ i.v. were infused from $\mathrm{T}-0$ to $\mathrm{T}+120 \mathrm{~min}$. The parameters shown are: fibrinogen (solid circles), protein C/activated protein C (open circles), SGPT (open squares), and HPC-4 $(\times-X),(n=3)$. 
These studies using a combination of HPC-4 antibody with lethal concentrations of $E$. coli established that the fall in protein $\mathrm{C}$ levels associated with $\mathrm{LD}_{100} E$. coli alone could be blocked with the HPC-4 antibody. This in turn suggested that the fall in protein $\mathrm{C}$ levels is due to its conversion to activated protein $\mathrm{C}$ and not due to inhibition of synthesis. Though the coagulopathic response to $E$. coli was more rapid and complete in the presence of this antibody, the response to $E$. coli alone was sufficiently severe that addition of the antibody could produce only quantitative not qualitative changes in what was already a severe lethal effect. Therefore, we repeated these studies infusing a sublethal ( $10 \%$ of the lethal concentration) concentration of $E$. coli organisms with and without the HPC-4 antibody to determine if the presence of HPC-4 could change an adequate protective response to $E$. coli into an inadequate one.

Infusion of sublethal numbers of $E$. coli organisms alone produced a rise in fibrinogen level above control beginning at $\mathrm{T}+120 \mathrm{~min}$. No changes in the plasma levels of protein $\mathrm{C}$ or SGPT were observed (Fig. 5). The three baboons so treated experienced a transient fall in leukocyte count and rise in temperature at $\mathrm{T}+120 \mathrm{~min}$. The arterial pressure and general clinical status of these animals remained stable throughout the study and they survived the full 7-d postoperative period. When, however, the infusion of sublethal numbers of $E$. coli organisms was preceded by an infusion of HPC-4 antibody to protein $C$ the response of fibrinogen, SGPT, leukocyte count and vital signs was almost identical to that seen following infusion of lethal numbers of $E$. coli alone (Figs. 2 and 6). Two of the three baboons so treated died by 32 hours.

To test the specificity of the effects of this combination of antibody to protein $\mathrm{C}$ and sublethal $E$. coli we repeated the above study infusing (exogenous) activated protein $C$. Under these conditions infusion of activated protein $\mathrm{C}$ in sufficient quantities to inhibit the coagulopathic response as reflected by the fibrinogen levels, also prevented both the hepatotoxic and lethal effects

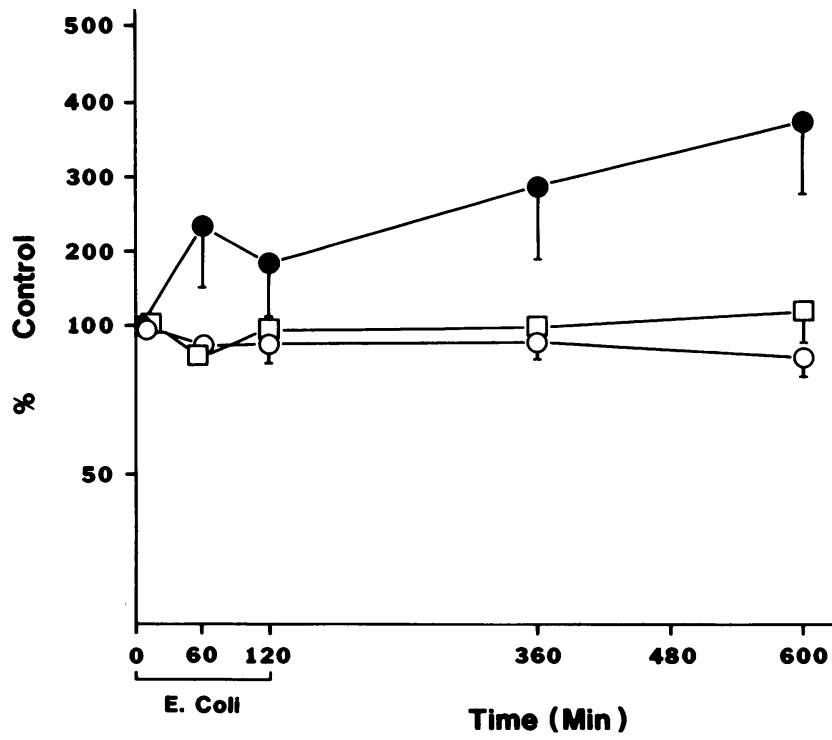

Figure 5. Response of baboons to sublethal concentrations of $E$. coli. After an equilibration period of $30 \mathrm{~min}, 0.4 \times 10^{10} \mathrm{E}$. coli organisms/ $\mathrm{kg}$ i.v. were infused from $\mathrm{T}-0$ to $\mathrm{T}+120 \mathrm{~min}$. The parameters shown are: fibrinogen (solid circles), protein C/activated protein $\mathrm{C}$ (open circles), and SGPT (open squares), $(n=3)$.

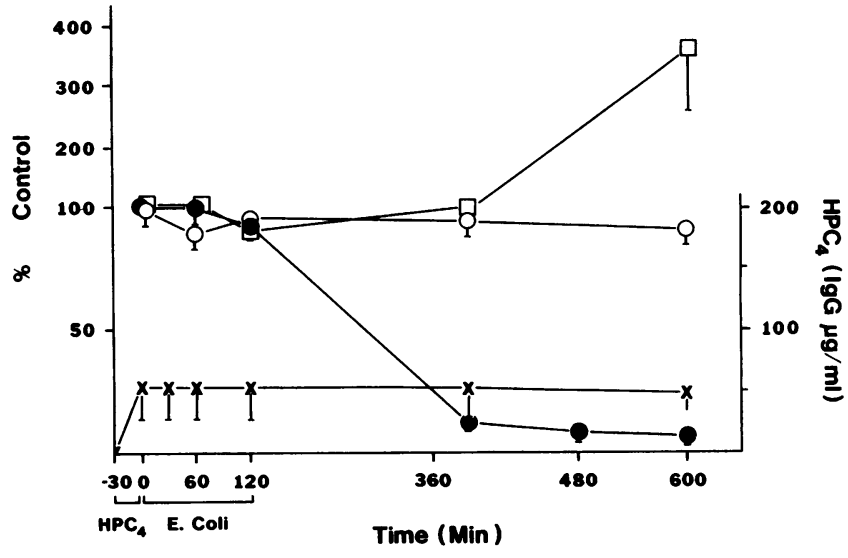

Figure 6. Response of baboons to an infusion of HPC-4 followed by sublethal concentrations of $E$. coli. After an equilibration period of 30 $\mathrm{min}, 4 \mathrm{mg} / \mathrm{kg}$ i.v. of HPC-4 were infused for $30 \mathrm{~min}$. After a second equilibration period of $30 \mathrm{~min}, 0.4 \times 10^{10} \mathrm{E}$. coli organisms $/ \mathrm{kg}$ i.v. were infused from $T-0$ to $T+120 \mathrm{~min}$. The parameters shown are: fibrinogen (solid circles), protein C/activated protein $\mathrm{C}$ (open circles), SGPT (open squares), and HPC-4 $(X-X),(n=3)$.

(Fig. 7). The three baboons so treated experienced a transient fall in leukocyte count as opposed to the sustained fall in the unprotected animals. The mean systemic arterial pressure and general clinical status remained stable throughout the study and they survived the full seven day postoperative period.

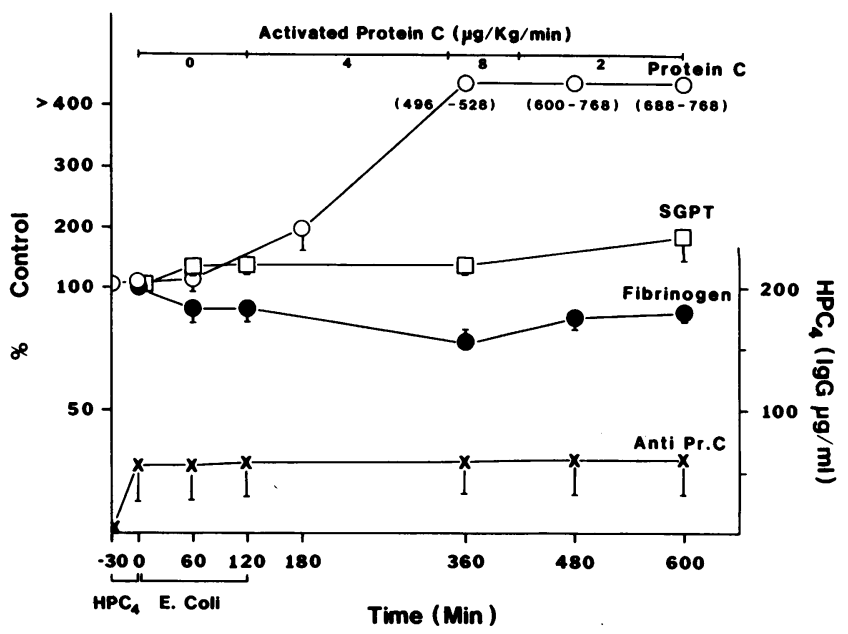

Figure 7. Response of baboons to an infusion of HPC-4 followed by activated protein $C$ and sublethal concentrations of $E$. coli. After an equilibration period of $30 \mathrm{~min}, 4 \mathrm{mg} / \mathrm{kg}$ i.v. of HPC-4 were infused for $30 \mathrm{~min}$. After a second equilibration period of $30 \mathrm{~min}$, infusions of $4 \mu \mathrm{g} / \mathrm{kg}$ per min of activated protein $\mathrm{C}$ and $0.4 \times 10^{10} \mathrm{E}$. coli were started at $\mathrm{T}-0$. The $E$. coli infusion was continued to $\mathrm{T}+120 \mathrm{~min}$. The activated protein $C$ infusion was continued to $T+600 \mathrm{~min}$. The rate of activated protein $\mathrm{C}$ infusion was adjusted to maintain the fibrinogen level at no less than $70 \%$ of baseline. Measurement of fibrinogen levels were required every $15 \mathrm{~min}$ from $\mathrm{T}+120$ to $\mathrm{T}+360 \mathrm{~min}$ in order to regulate the rate of activated protein $C$ infusion. The rates of activated protein $\mathrm{C}$ infusion are shown at the top of the figure. The parameters shown are: fibrinogen (solid circles), protein C/activated protein C (open circles), SGPT (open squares), and HPC-4 $(X-X),(n=3)$. 
The leukocyte responses relative to those of the fibrinogen degradation products, platelet, SGPT, and protein C are summarized in Table III. The data in this table describe the observed responses in three experimental models $(a)$ infusion of $E$. coli (lethal) alone, (b) infusion of $E$. coli (sublethal) plus HPC-4, and $(c) E$. coli (lethal) plus activated protein $C$. The responses in $a$ and $b$ can be divided into four stages. In stage 1 , the fall in leukocyte count was complete by $\mathrm{T}+120 \mathrm{~min}(2 \mathrm{~h})$. In stage 2 , the fall in fibrinogen and concomitant rise in fibrin degradation products was complete by $\mathrm{T}+360 \mathrm{~min}(6 \mathrm{~h})$. It also should be noted that this rise in fibrin degradation products was preceded by markedly increased rates of whole blood clot lysis at $T+120$ min. The fibrinolytic activity of whole blood at $T-0$ and $T+60$ min and of whole blood reconstituted with fibrinogen at $T+180$, 240 , and 360 min was $<10 \%$ of that observed in blood drawn at $T+120$ min. In stage 3, a rise in SGPT levels begin at $T+360$ and was clearly evident by $T+600 \mathrm{~min}(10 \mathrm{~h})$. In stage 4 , the fall in mean systemic arterial pressure which began at $T+120$ min became clinically significant at $T+480 \mathrm{~min}$. The protein $\mathrm{C}$ levels and platelet counts fell steadily throughout the 10 -h observation period. Over the ensuing $12-20 \mathrm{~h}$, platelets and protein $C$ levels continued to fall together with the mean systemic arterial pressure eventuating in death at 24-32 h.

In the animals where activated protein $\mathrm{C}$ was infused together with the $E$. coli, all these responses except the fall in leukocyte count and the appearance and extent of increased whole blood clot lysis activity were attenuated. Leukocytes did return to near normal more rapidly however, when the animals were treated with activated protein $\mathrm{C}$. Hematocrits did not vary from control by $>10 \%$ during the course of any of these studies.

\section{Discussion}

These studies demonstrate that activated protein $\mathrm{C}$ can function as an effective in vivo anticoagulant without causing severe bleeding complications. In addition to preventing the coagulopathic response which follows infusion of $E$. coli, activated protein $\mathrm{C}$ also prevents the lethal effects. Whether all of the protective effects observed are mediated through the anticoagulant activity of activated protein $C$ is uncertain. Although administration of activated protein $\mathrm{C}$ does protect the baboons relatively high concentrations are required. This raises the question of whether protein $C$ plays a natural role in the defense against gram negative sepsis. Several lines of evidence suggest that it does. First, protein $C$ levels decrease after $E$. coli infusion, and since when we block protein $\mathrm{C}$ activation, this decrease is also blocked, it appears that in this animal model the decrease is due to protein $\mathrm{C}$ activation and not inhibition of synthesis, as has been suggested in patient studies (23-25). Second, when protein C activation is blocked, the concentration of $E$. coli required to elicit a lethal response is reduced at least 10 -fold. Under these conditions, the baboons were protected if administered exogenous activated protein $\mathrm{C}$. Although it is our impression that relatively high concentrations of activated protein $\mathbf{C}$ may be required, we have not attempted a study to determine the minimum concentrations required.

Several factors may account for the relatively large amount

Table III. Summary of the Response of Inflammatory, Hemostatic, Cardiovascular and Hepatocellular Parameters to Infusions of E. coli (Lethal); E. coli (Sublethal) Plus Antibody to Protein C; and E. coli (Sublethal) Plus Antibody to Protein C Plus Activated Protein C

\begin{tabular}{|c|c|c|c|c|c|c|c|c|}
\hline Time (min) & 0 & 60 & 120 & 240 & 360 & 480 & 600 & \\
\hline \multirow{3}{*}{ Leukocytes } & 100 & - & 15 & 15 & 15 & - & 20 & E. coli (lethal) \\
\hline & 100 & 77 & 15 & - & 34 & - & 44 & E. coli (sublethal) + HPC-4 \\
\hline & 100 & 59 & 29 & 38 & 53 & - & 61 & $E$. coli (lethal) + APC \\
\hline \multirow[t]{3}{*}{ Fibrinogen } & 100 & 100 & 78 & 16 & 21 & - & 9 & \\
\hline & 100 & 100 & 93 & 12 & 7 & - & 6 & \\
\hline & 100 & 85 & 88 & 79 & 78 & 100 & 90 & \\
\hline \multirow{3}{*}{$\mathrm{FDP}(\mu \mathrm{g} / \mathrm{ml})$} & $<10$ & $<10$ & $<10$ & 723 & 1280 & - & 1600 & \\
\hline & $<10$ & $<10$ & 160 & 800 & - & - & 1920 & \\
\hline & $<10$ & $<10$ & $<10$ & $<10$ & 10 & - & $<10$ & \\
\hline \multirow[t]{3}{*}{ SGPT } & 100 & 102 & 86 & 182 & 197 & - & 438 & \\
\hline & 100 & 111 & 120 & 110 & - & - & 380 & \\
\hline & 100 & - & 100 & 100 & - & - & 160 & \\
\hline \multirow[t]{3}{*}{ MSAP } & 100 & 79 & 61 & 63 & 67 & 48 & 40 & \\
\hline & 100 & 97 & 64 & 50 & 56 & 56 & 60 & \\
\hline & 100 & 100 & 90 & 63 & 70 & 70 & 80 & \\
\hline \multirow[t]{3}{*}{ Protein C } & 100 & 123 & 110 & 103 & 74 & 52 & 46 & \\
\hline & 100 & 102 & 98 & 105 & 92 & 98 & 103 & \\
\hline & 100 & 413 & 652 & 816 & 705 & 768 & 768 & \\
\hline \multirow[t]{3}{*}{ Platelets } & 100 & 85 & 72 & 54 & 54 & 20 & 20 & \\
\hline & 100 & 100 & 70 & 62 & 52 & - & 28 & \\
\hline & 100 & - & 70 & 64 & 56 & 50 & 50 & \\
\hline
\end{tabular}


of activated protein $\mathrm{C}$ required to protect the animals in the $\mathrm{LD}_{100}$ model. First, and most obvious, this model constitutes a severe challenge with which natural defense mechanisms cannot cope. In this setting it may be reasonable to require very high levels. Second, human activated protein $\mathrm{C}$ may be less effective in the baboon either because of specificity toward Factor Va or VIIIa (8-11) ability to complex with protein $S$ or the ability to interact with cellular receptors on the platelet (26) or endothelial cell (27). Third, protein $C$ activated on the surface of the endothelium (28) may be more effective than the infused preparations. Finally, it is worth noting that plasma derived activated protein $C$ proved approximately twice as effective than that derived from KONYNE in preventing $E$. coli induced consumption of fibrinogen.

One feature we have observed over several years of animal experiments with activated protein $\mathrm{C}$ is that no animal has ever exhibited detectable bleeding. The studies on Factor V and VIII levels provided here may aid in explaining this finding. Both factors clearly remain high following activated protein $\mathrm{C}$ infusion. This indicates that in vivo, when activated protein $\mathrm{C}$ functions on cellular receptors, activated protein $\mathrm{C}$ does not significantly degrade these precursors. This differs from the plasma system with phospholipid where Marlar et al. have described inactivation of the precursors (29). Based on the observations that the principle substrates are the activated forms of Factor $V(8,9)$ and VIII $(10,11)$, we hypothesized that the in vivo anticoagulant activity is mediated through inactivation of these forms. One potential mechanism for increasing the in vivo specificity of activated protein $\mathrm{C}$ for activated Factor $\mathrm{V}$ is suggested by the observation that binding of activated protein $C$ to the surface of unstimulated platelets is dependent on the presence of both Factor $\mathrm{Va}$ and protein $\mathrm{S}(30)$. Thus the activated Factor $\mathrm{V}$ (and possibly Factor VIII) may be required for assembly of functional anticoagulant complexes. This anticoagulant activity can be minimized however if Factor $\mathrm{Xa}$ is formed since the Factor $\mathrm{Xa}$ Va complex is relatively resistant to activated protein $C$ either on platelets (9) or on liposomes (31). Thus at localized regions where Factor $X$ activation may be high due to trauma, the potential exists to overcome this anticoagulant system.

One question to arise from this study is whether the observed effects of activated protein $\mathrm{C}$ might not be due to a contaminant in the preparation rather than the protein $C$ itself. Although we know of no way to totally exclude this possibility, several lines of evidence suggest that it is unlikely. First, the isolated protein is essentially homogeneous when isolated from plasma. The monoclonal antibody gives in a two step procedure an $\sim 10,000$ fold purification. The only detectable contaminant is serum amyloid $\mathrm{P}$, which binds to the gel matrix in the presence of $\mathrm{Ca}^{2+}$ and is separated on the QAE columns. Second, this monoclonal antibody to protein $C$ enhances the sensitivity to $E$. coli suggesting that protein $C$ is involved in host defence and this antibody effect is overcome with exogenous activated protein $\mathrm{C}$.

The simplest mechanism by which activated protein $\mathrm{C}$ may function in this shock model is as an anticoagulant. This raises the question of whether anticoagulation alone is sufficient to protect from the lethal influence of $E$. coli. In particular, complement activation (32) and elaboration of monokines (33) have been suggested to be major mediators of the toxic effects observed with endotoxin. Cerami's group has shown that in mice, passive immunization against cachectin/tumor necrosis factor prevents the lethal effects of $E$. coli. The mechanism by which this monokine contributes to these lethal effects is uncertain, but among the possibilities is that TNF initiates coagulation by inducing tissue factor and by inhibiting protein $\mathrm{C}$ activation through inhibition of thrombomodulin activity (34). This link between the elaboration of TNF and the coagulopathic response observed in the animals raised the question of whether activated protein $C$ might also function by inhibiting TNF elaboration. This possibility will be explored in future studies.

\section{References}

1. Hinshaw, L. B., B. D. Cox, editors. 1972. The fundamental mechanisms of shock. Plenum Publishing Corp., New York. 311-320.

2. McKay, D. G. 1964. Disseminated Intravascular Coagulation (DIC): An Intermediary Mechanism of Disease. Harper and Row Publishers, New York.

3. Taylor, F. B., A. K. Chang, L. B. Hinshaw, C. T. Esmon, L. T. Archer, and B. K. Beller. 1984. A model for thrombin protection against endotoxin. Thromb. Res. 36:177-185.

4. Comp, P. C., R. M. Jacocks, G. Ferrell, and C. T. Esmon. 1982. Activation of protein $C$ in vivo. J. Clin. Invest. 70:127-133.

5. Wetmore, R., and V. Gurewich. 1974. The role of fibrin monomoner and an in vivo thrombin-induced-anticoagulant in experimental venous thrombosis. Scand. J. Haematol. 12:204-212.

6. Comp, P. C., and C. T. Esmon. 1981. Generation of fibrinolytic activity by infusion of activated protein $\mathrm{C}$ into dogs. J. Clin. Invest. 68 : 1221-1228.

7. Taylor, F. B., Jr., M. Lockhart, A. D'Angelo, and S. Vigano-D'Angelo. 1986. Protein $S$ is a cofactor for activated protein $C$ neutralization of an inhibitor of plasminogen activation (antiactivator) released from platelets. Blood. In press.

8. Kisiel, W., L. H. Erickson, and E. W. Davie. 1976. Proteolytic activation of protein $C$ from bovine plasma. Biochemistry. 15:48934900.

9. Walker, F. J., P. W. Sexton, and C. T. Esmon. 1979. The inhibition of blood coagulation by activated protein $C$ through selective inactivation of activated factor V. Biochim. Biophys. Acta. 571:333-342.

10. Vehar, G. A., and E. W. Davie. 1980. Preparation and properties of factor VIII. Biochemistry. 19:401-410.

11. Marlar, R. A., A. J. Kleiss, and J. H. Griffin. 1982. Mechanism of action of human activated protein $\mathrm{C}$, a thrombin-dependent anticoagulant enzyme. Blood. 59:1067-1072.

12. Rodeghiero, F. R., P. M. Mannucci, S. Vigano, T. Barberi, L. Gugliotta, M. Cortellaro, and E. Dini. 1984. Liver dysfunction rather than coagulation as the main cause of low protein $\mathrm{C}$ and antithrombin III in acute leukemia. Blood. 63:965-969.

13. Hougie, C. 1978. Methods for estimating fibrinogen concentration. Thrombin time test. In Hematology. W. J. Williams, E. Beutler, A. J. Erslev, and M. A. Lichtman, editors. Third ed. McGraw Hill Book Co., New York. A35:1667-1668.

14. Taylor, F. B., and M. S. Lockhart. 1985. Whole blood clot lysis. In vitro modulation by activated protein C. Thromb. Res. 37:639-649.

15. Wellcome Research Laboratories. Fibrinogen degradation products. Thrombo-Wellcotest-(Rapid Latex Kit).

16. Wroblewski, F., and J. S. LaDue. 1956. Serum glutamic pyruvic transaminase in cardiac and hepatic disease. Proc. Soc. Exp. Biol. Med. 91:569-571.

17. Hinshaw, L. B., D. J. Brackett, L. T. Archer, B. K. Beller, and M. F. Wilson. 1983. Detection of the "hyperdynamic state" of sepsis in the baboon during lethal $E$. coli infusion. J. Trauma. 23:361-365.

18. Kappela, R. 1955. Das Verhalten. Factor V in serum unter normalen und pathologischen bedingungen. Zeitschrift fur Klinische Medizine. 153:103-113.

19. Ingram, G. I. C. 1982. Bleeding Disorders: Investigation and Management. Second ed. Blackwell Scientific Publications, Boston, MA. 316-317.

20. Laurell, C. B., and E. J. McKay. 1981. Electroimmunoassay. Methods Enzymol. 73:359-369. 
21. Vigano, S., P. C. Comp, C. T. Esmon, and A. D'Angelo. 1986. Relationship between protein $\mathrm{C}$ antigen and anticoagulant activity during oral anticoagulation and in selected disease states. J. Clin. Invest. 77: 416-425.

22. Coalson, J. J., B. A. Benjamine, L. T. Archer, B. K. Beller, R. H. Spaet, and L. B. Hinshaw. 1978. A pathologic study of E. coli shock in the baboon and the response to adrenal corticosteroid treatment. Surg. Gynecol. Obstet. 147:726-736.

23. Mannucci, P. M., and S. Vigano. 1982. Deficiencies of protein $C$, an inhibitor of blood coagulation. Lancet. ii:463-467.

24. Griffin, J. H., D. F. Mosher, T. S. Zimmerman, and A. J. Kleiss. 1982. Protein C, an antithrombotic protein, is reduced in hospitalized patients with intravascular coagulation. Blood. 60:261-264.

25. Rodeghiero, F., P. M. Mannucci, S. Vigano, T. Barbui, L. Gugliotta, M. Cortellaro, and E. Dini. 1984. Liver disfunction rather than intravascular coagulation as the main cause of low,protein $\mathrm{C}$ and antithrombin III in acute leukemia. Blood. 63:965-969.

26. Harris, K. W., and C. T. Esmon. 1985. Protein $S$ is required for bovine platelets to support activated protein $C$ binding and activity. $J$. Biol. Chem. 260:2007-2010.

27. Stern, D. M., P. P. Nawroth, K. W. Harris, and C. T. Esmon. 1986. Cultured bovine aortic endothelial cells promote activated protein
C-protein S-mediated inactivation of factor Va. J. Biol. Chem. 261:713718.

28. Esmon, C. T., and W. G. Owen. 1981. Identification of an endothelial cell cofactor for thrombin-catalyzed activation of protein $\mathrm{C}$. Proc. Natl. Acad. Sci. USA. 78:2249-2252.

29. Marlar, R. A., A. J. Kleiss, and J. H. Griffin. 1982. Mechanism of action of human activated protein $\mathrm{C}$, a thrombin-dependent anticoagulant enzyme. Blood. 59:1067-1072.

30. Harris, K. W., and C. T. Esmon. 1985. Protein S binds to unstimulated platelets. Xth International Congress on Thrombosis and Haemostasis. 54:58, 0339. (Abstr.)

31. Nesheim, M. E., W. M. Canfield, W. Kisiel, and K. G. Mann. 1982. Studies of the capacity of factor Xa to protect factor Va from inactivation by activated protein C. J. Biol. Chem. 257:1443-1447.

32. Sacks, T., C. T. Moldow, P. R. Craddock, T. K. Bowers, and H. S. Jacobs. 1978. Oxygen radicals mediate endothelial cell damage by complement stimulated granulocytes. J. Clin. Invest. 61:1161-1167.

33. Beutler, B., T. W. Milsark, and A. C. Cerami. 1985. Passive immunization against cachectin/tumor necrosis factor protects mice from the lethal effects of endotoxin. Science (Wash. DC). 229:869-871.

34. Gajdusek, C., S. Carbon, R. Ross, P. P. Nawroth, and D. M. Stern. 1986. Activation of coagulation releases endothelial cell mitogens. J. Cell Biol. 103:419-428. 